\title{
Forging a Revolutionary Army: The All-Russian Military Union in 1917
}

\author{
Matthew Rendle \\ University of Exeter
}

\begin{abstract}
The Russian military was deeply divided after the February Revolution of 1917, but if Russia was to emerge victorious from the First World War, it needed to forge a unified revolutionary army. This article examines the only serious attempt to foster unity, the All-Russian Military Union. Whilst the union was not successful, a study of its activities emphasizes that divisions existed within social groups in the military as well as between them, which were exacerbated by the authorities. It also sheds light on the role of unions in the military and across Russia in 1917.
\end{abstract}

Keywords: Russian military, First World War, revolution, unions, social conflict

The February Revolution of 1917 exposed deep divisions in the Russian military. ${ }^{1}$ Tsar Nicholas II was still on the throne when soldiers in Petrograd pledged their allegiance to the popularlyelected Soviet of Workers' and Soldiers' Deputies. On 1 March 1917, the Soviet published Order No. 1, which declared that soldiers were granted full civil rights and should immediately elect representatives to committees. These committees, not officers, should control arms, whilst forms of deference to superiors were abolished. ${ }^{2}$ Soldiers' committees proliferated over subsequent 
weeks, intervening in every aspect of military life, including operations. ${ }^{3}$ Above all else, most soldiers desired an end to the First World War, whose destructive impact on Russia had exacerbated their grievances. After Nicholas's abdication, the new Provisional Government called for a defensive war and the Soviet pledged its tentative support. But whilst the soldiers accepted this call in the short term, it was clear to observers that the military's fighting capabilities had been seriously undermined and this decline promised to continue.

Officers had a very different view of the revolution. Most saw it as an opportunity to galvanize the war effort, providing a more effective government that could unite the country in a final push to victory. ${ }^{4}$ A small number of socialist officers formed the Union of Republican Officers to support the Soviet. Larger numbers gathered in soviets of officers' deputies in Petrograd and Moscow, marshalling support for the Provisional Government. Both accepted the need for further reform. Within weeks, however, other officers, probably reflecting the mood of the majority, started to press for an end to reform, a return of authority to officers, and the restoration of order and stability in Russia. All of this, they believed, was essential to win the war. These feelings were reflected in the formation of the conservative Military League in late March and plans from mid-April to form a Union of Officers. ${ }^{5}$

All of these bodies - committees and unions - only reinforced the chasm between officers and soldiers. Membership of the Military League was open to all those who supported its aims (even civilians), whilst soldiers and officers held the St George military honours required to join another conservative body, the Union of George Cavaliers, but officers dominated both. ${ }^{6}$ Equally, although the government hoped that officers would be well represented on soldiers' committees, only $7-11 \%$ of members were officers. ${ }^{7}$ However, if Russia was to defend itself against the German threat, then a revolutionary army had to be forged from the events of February 1917 and some degree of unity between both groups was essential. 
This article examines the only serious attempt to build an organization to promote unity, the All-Russian Military Union. The union is barely mentioned in existing studies, probably because it was unsuccessful. ${ }^{8}$ Nonetheless, utilizing archival records, this article argues that its activities, alongside the problems it faced, reveal important elements of the revolutionary process. The union's experiences reinforce the sense that the divisions in the military were irreconcilable, reflected those of wider society, and demonstrated that different visions of the future lay at the heart of the revolutionary process. This has been noted, ${ }^{9}$ but the union highlights deep divisions within social groups as well as between them. Its activities show that a patriotic desire to continue the war remained strong among some soldiers despite widespread demands for peace. Furthermore, one would expect an attempt to promote unity in the military to be supported by the authorities. The Soviet was unresponsive, the government ambiguous, and whilst the High Command (Stavka) helped the union, it provided more support to officers' unions. As 1917 progressed, then, divisions did not only emerge from below, from soldiers and officers, but were also fostered from above as the authorities seemed determined to enforce their own views rather than compromise. Nonetheless, the union's persistence throws light on the changing nature of Russia's political culture, demonstrating that in the absence of real democracy in 1917 , such unions could enjoy a greater presence than their minority status warranted.

Ironically, the All-Russian Military Union emerged from the creation of new union for officers. On 12 April, the Soviet of Officers' Deputies in Petrograd announced plans to hold a conference. A group of staff officers at Stavka (situated in Mogilev, behind the western front) had serious misgivings. One of these, Lieutenant-Colonel D. A. Lebedev, recalled later that Stavka had been 
receiving daily reports chronicling the disintegration of the military due to the activities of committees and the declining authority of officers. They felt that officers in Petrograd were divorced from events and were inaccurately representing the views of frontline officers, leaving the government unaware of the seriousness of events. They believed that Stavka needed to act. They met on 15 April and formulated plans for a new union of officers. They urged officers to start forming the union and proposed their own rival congress to formally sanction it. ${ }^{10}$

On 5 May, delegates already in Mogilev met in a private meeting to discuss the priorities of the forthcoming congress, which was to start officially on 7 May. Lebedev emphasized that the main aim was to create a powerful union to represent officers. But, from the start, it proved impossible to ignore soldiers. The weeks following the announcement of the congress had seen widespread concern gather among soldiers at the thought of a congress (and a union) solely for officers. It would widen the gulf between officers and soldiers, whilst it was superfluous; soldiers argued that if officers wanted to engage with the revolution, they could participate in soldiers' committees. Regiments from across Russia sent almost 200 representatives to observe the congress, specifically tasked to search for signs of counter-revolutionary tendencies. ${ }^{11}$

The first debate concerned whether these soldiers should participate in the congress and be entitled to vote on proceedings. This prompted a furious argument among the officers. As one argued, 'why is it that whenever officers speak or gather, the question always arises - what about the soldiers?' For him, this congress was for officers not soldiers, and it was driven by the belief that their voices were being drowned out by soldiers' demands. The debate became 'hysterical' and had to be halted temporarily whilst calm was restored. Eventually, the officers, presumably fearful of the power of the soldiers, voted narrowly to permit them the right to a full vote. After all that, the soldiers declined, expressing their desire simply to observe proceedings. ${ }^{12}$ 
This debate revealed that not all of the officers present were convinced that plans to form a union of officers were desirable. As the congress started, the soldiers observed three clear groups of officers. The first, led by the organizers, was focused on using the congress as a means to form a new union solely for officers. The second was of the opposite opinion; only unity could benefit Russia during the current political and military turmoil. If a union was needed, it should include officers and soldiers. The final group was undecided - 'neither ours, nor theirs', as the observing soldiers phrased it. ${ }^{13}$

The soldiers believed that the only acceptable outcome was a conference of officers, soldiers and other military personnel, and a union based on these foundations. They took heart from the fact that A. F. Kerenskii, the socialist Minister of War, sent a telegram to the congress saying as much. ${ }^{14}$ After an inconclusive debate on this idea among officers on 8 May, the soldiers demanded the election of a committee to organize such a conference. They resolved to walk out if the officers refused. A day later, the congress's organizers agreed, but contested the composition of this committee. The soldiers argued that it should contain two soldiers for every officer, thereby reflecting the overwhelming preponderance of soldiers in the military. The officers, however, demanded equal representation. The soldiers stuck to their position and by 14 May, having met with no success, decided to form the committee anyway, inviting sympathetic officers to join. On 15 May, the soldiers' proposals were finally accepted, and an organizing committee was formed from twenty soldiers and ten officers. ${ }^{15}$

Although the organizing committee often acted as if a union existed, all that had been agreed was to form a committee to organize a conference of military personnel, which would then vote on an All-Russian Military Union. Many officers still doubted the value of this step and this was reflected in the fact that the congress continued its plans to form a new union for officers. On 21 May, the Union of Officers of the Army and the Fleet was created with a main 
committee and formal regulations. It quickly established branches across the military, published its own newspaper and promoted officers' views energetically. If the proposed Military Union was to match this, it needed a fair amount of further work.

Lieutenant-Colonel L. N. Novosil'tsev, the chairman of the congress and president of the Union of Officers, argued later that those officers who were supportive of the soldiers' demands had forgotten their self-respect and honour. ${ }^{16} \mathrm{He}$ and other leading officers were determined to create an officers' union and managed the agenda accordingly. Even the public record - daily telegrams distributed across the front on the congress's activities - emphasized officers' concerns over proposals to form a military union. ${ }^{17}$ Novosil'tsev felt that Kerenskii's support had encouraged sceptical soldiers to seize on this idea to frustrate the original aims of the congress, whilst additional pressure from some officers forced him to agree to the organizing committee. He claimed that the soldiers made far more demands than their account suggests; desiring five representatives for every officer, for example. The Union of Officers did publicize the organizing committee as one of the achievements of the congress, but there appears to have been little cooperation between the two groups. ${ }^{18}$

This lack of enthusiasm did not auger well for the Military Union and evidence suggests further tensions between soldiers and officers. On 17 May, two days after the committee was formed, the soldiers on it wanted to issue an appeal declaring that any officers who did not recognize the Provisional Government, support the role of the Soviet, and who desired a return to Tsarism, should be excluded from the new revolutionary army as traitors. Officers, however, believed that this appeal was too sharp and uncompromising, arguing that no-one wanted a return to the past or opposed the Provisional Government. ${ }^{19}$

The result of the dispute is unclear, but the marriage of officers and soldiers was fated to be uneasy. For those officers at the front who believed that they deserved their own union to 
promote their views as a counterbalance to soldiers' committees, the Military Union was another body dominated by soldiers. At the same time, the plans were unlikely to foster much enthusiasm among the wider mass of soldiers. Most believed that democracy should only benefit the lower social classes; as one soldiers' committee noted, 'if you [the government] defend the poor class, then there will be a democratic republic, but if you defend the interests of the capitalists, then Russia is lost' ${ }^{20}$ In the military, the revolution had provided a voice for soldiers through their committees and soviets; there was no need for any type of union with officers. Nevertheless, the commitment of those soldiers involved demonstrates that they felt that there was a role for this new union. In this, they must have been encouraged by the multitude of unions and societies emerging across Russia representing all manner of groups. Clearly, forming a union was seen as a valuable means of consolidating support and promoting interests in revolutionary Russia.

\section{II}

The thirty-man executive bureau (as the organizing committee became known) started working from 15 May on creating an All-Russian Military Union that would become the authoritative voice for the entire military. The union's aims were to help strengthen the fighting capabilities of the military, improve discipline, and increase the level of unity between soldiers and officers, all of which would help Russia emerge victorious from the war. After victory, the union would facilitate demobilization, and provide aid to invalids and the families of victims. ${ }^{21}$ In the shortterm, a conference was seen as essential to agree the rules and regulations of the union and elect a leadership, whilst mustering support and providing much-needed publicity.

It is very difficult to say much about the individuals involved. A later list indicated 33 people associated with the bureau, ${ }^{22}$ whilst the archives suggest that around 40 people acted for 
the union at some stage, but only about a dozen were active for any period of time. Their backgrounds are difficult to trace. The two best known officers, Lebedev and Colonel K. V. Sakharov, hardly participated. Both were graduates of the elite General Staff academy and were active in other, more conservative, organizations - the Union of Officers and Union of George Cavaliers respectively. Both fought against the Bolsheviks after October. Otherwise, the officers involved held the ranks of lieutenant, captain, and colonel. There was only one ensign, the lowest and often most radical rank of officer. There were also two doctors and three sailors.

The bureau suffered an immediate setback. Novosil'tsev noted that its members travelled to Petrograd after the congress to liaise with the Soviet. He wrote that they received a frosty welcome, which the bureau admitted later, and suggests that the Soviet was afraid that the union would encroach on its activities. ${ }^{23}$ The Soviet probably felt that the union was unnecessary. The rival officers' congress in Petrograd (8-27 May) was far more inconclusive than its counterpart in Mogilev. Discussions had focused on establishing a role for officers within a reformed military rather than the narrower focus on forming a union to voice officers' concerns. ${ }^{24}$ The Soviet also sponsored another body, the Union of Republican Officers, which transformed in late April into the Union of Socialists of the People's Army. It aimed to attract officers and soldiers supporting democratic (socialist) principles and the Soviet. ${ }^{25}$ Given that the greatest emphasis remained on soldiers' committees, the Soviet must have seen little need for yet another body.

The bureau also received an unenthusiastic response from the Provisional Government, which was more worrying. As Minister of War, Kerenskii sent a supportive message on hearing of plans to form a military union and another such message after the bureau was created. ${ }^{26}$ Yet the bureau noted that Kerenskii rebuffed their advances after the congress. ${ }^{27}$ No reason was provided, but the government looked to the soviets of officers established in many towns for support. Most of these soviets, on paper at least, were committed to working with the soldiers. 
The regulations agreed at the first assembly of Moscow's Soviet of Officers' Deputies on 7 March, for instance, envisaged it as a counterpart to the Soviet of Soldiers' Deputies and that representatives from both would converge in a military council. This council - 22 soldiers and 11 officers - should have real power over the region's military. These officers hoped that both soviets would form a united body in due course. ${ }^{28}$ Similar links were extolled elsewhere. ${ }^{29}$ Whether such ambitions were fulfilled is debatable, but, on the surface, it seemed to the government as if moves towards unity were already occurring.

The bureau's uneasy relationship with the Soviet and the government probably hindered its attempts to organize a conference, but it was unfortunate in its timing. The bureau decided to invite 1,860 delegates; 1,140 soldiers, 570 officers, and 150 doctors, clergy and others. Such a conference, it argued, would foster unity and lay the foundations for a new military that would place defending the motherland and freedom above party politics. Equally, this conference would provide the Military Union with the mandate it needed. The bureau encouraged soldiers and officers to start organizing the union by electing 15-20 soldiers per regiment, along with half as many officers, with each regimental branch sending several representatives to a divisional branch, which would then liaise with the bureau. ${ }^{30}$

However, on 30 May, a meeting of the bureau noted that Kerenskii had forbidden the conference the day before. Presumably with plans for the forthcoming offensive in mind (see below), he argued that military personnel must be fulfilling their duties at the current time. The bureau resolved to question this decision, but it was not reversed. ${ }^{31}$ This left the bureau in a quandary. Without a conference, it was difficult for the bureau to claim that it represented any particular group within the military or had a mandate to speak in anyone's name. Moreover, anyone could create a union, something confirmed by law on 12 April, but for a union to own property and have legal rights, it needed to be registered. To be registered, it had to submit copies 
of its regulations to the authorities. ${ }^{32}$ The bureau may have been able to do this itself, but clearly felt that the regulations should be ratified by a conference. It clearly hoped that permission was imminent, but the continued ban frustrated these ambitions. Meanwhile, the ambiguous legal position of the union restricted the bureau's room for manoeuvre.

III

By late May, preparations were underway for an offensive to reinvigorate the war effort and to strengthen Russia’s position in any forthcoming peace negotiations. Russian armies on the southwest front attacked on 18 June, enjoying a couple of days of steady advance before the Germans rallied. Despite a supporting attack on the western front from 7 July, the offensive collapsed, serving only to emphasise the extent of soldiers' disillusionment and the level of disintegration in the military since February. ${ }^{33}$ Nonetheless, the bureau, given that its plans for a military union were driven by pro-war sentiments, felt that it was justified to support the offensive. This support took two main forms; units or battalions of death and pro-war agitation across the front.

Battalions of death emerged from attempts to rejuvenate the Russian military prior to the offensive. Various 'shock' units had already emerged during the winter of 1916-17 to focus the best troops where most needed at the front, but the formation of these gathered pace after General A. A. Brusilov became Commander-in-Chief on 22 May. Moreover, in his previous post as Commander of the South-West Front, Brusilov had sponsored a proposal agreed at a congress of delegates from that front on 16 May to form revolutionary battalions. ${ }^{34}$ Contemporaries and historians often tend not to distinguish between the two, but on 27 June, Brusilov clarified that shock units consisted of volunteers from the active military at the front, whilst revolutionary battalions were formed from reserve units, trainee officers and civilian volunteers. ${ }^{35}$ 
Some evidence suggests that the term 'battalions of death' also came into use at around this time to describe units that vowed to never surrender and fight to the death; certainly, the creation of a women's battalion of death started in late May. ${ }^{36}$ One historian, though, wrote that Brusilov first bestowed the title of 'battalion of death' on a unit vowing to fight until its last drop of blood on 14 June. ${ }^{37}$ What is clear is that inspired by the bravery of this unit, Brusilov permitted the bureau to dispatch a telegram across the military on 18 June urging more units to adopt this vow and become 'units of death'. ${ }^{38}$ Both shock units and revolutionary battalions could use the epitaph 'of death'. Individuals in shock units were then permitted to wear a red-and-black chevron on their right arm and display the skull-and-cross bones on their cap. Those in revolutionary battalions could wear less visible distinguishing marks on their uniforms. ${ }^{39}$

Earlier, on 3 June, the All-Russian Central Committee for Organizing a Volunteer Revolutionary Army had been established to promote revolutionary battalions and a committee was created at Stavka a fortnight later to coordinate its response. As well as sending speakers across the front to gather volunteers, the All-Russian Central Committee had helped create committees in 23 regions, 69 districts and 4 fronts by early August to foster local activities. ${ }^{40}$ Some military organizations were suspicious, feeling that these new innovations could form a counter-revolutionary threat (Union of Socialists of the People's Army), or may weaken the military further by making its strongest elements more susceptible to casualties or, in the case of revolutionary battalions, infiltration by civilian socialist agitators (Union of Officers). ${ }^{41}$ But others, such as the Military League and Union of George Cavaliers, reacted enthusiastically and made plans to sponsor their own revolutionary battalions and shock units. ${ }^{42}$

The bureau argued that this was exactly the sort of activity that would foster unity and aid the war effort. In a report to the Commander-in-Chief in early August, which was copied to the staffs of all fronts, it expressed its conviction that if the whole army became an 'army of death' 
then it would be reborn, capable of repeating the glories of the past and defending the motherland and freedom. ${ }^{43}$ Moreover, sponsoring battalions of death promised to provide the Military Union with a source of support across the military in readiness for when a conference was permitted.

By July 1917, the bureau claimed to have created over 200 battalions of death consisting of around 600,000 men. By late August-early September, the number had reached 290-300 battalions with around 700,000 men. By late October, the figures had risen further to around 400 battalions and over 800,000 men. ${ }^{44}$ These claims are difficult to verify. It is clear that not all were 'battalions' as such, but ranged from corps and divisions to regiments and battalions. ${ }^{45}$ Even so, one historian has recently noted that some of Stavka's own records provide evidence for only 106 units adopting the epitaph 'of death' prior to October and an official document on 15 July listed just over $50 .{ }^{46}$ The bureau's figures are also similar to those provided by some historians for the number of shock units and revolutionary battalions as a whole. ${ }^{47}$ It is likely that no exact numbers exist and whilst some statistics include units of death within lists of shock units and revolutionary battalions, others list them separately. ${ }^{48}$ That said, it is possible that the bureau was generous with its statistics, probably to exaggerate its own importance in a policy that involved other bodies and the initiative of the troops themselves. Nonetheless, the bureau's archive is dominated by records concerning battalions of death, demonstrating, at the very least, that it devoted the majority of its effort to this area, which constituted its greatest success. ${ }^{49}$

The bureau assumed that because people formed these battalions, they sympathized with the union's ideals and would join when it was formally established. The bureau, therefore, used these figures in lieu of membership statistics in correspondence with higher authorities. It continued to urge supporters to form cells of the union across the military, spread literature and promote the need for a conference. The archives contain letters of support and requests for information about the union, which indicate interest in the bureau's activities, but it is difficult to 
ascertain the true level of active support. In early June, the union cited a figure of over 500 officers and soldiers as supporters, representing more than 200 different parts of the military. ${ }^{50}$ This seems to be a realistic assessment at this stage. Almost 200 soldiers had been present at the May congress, whilst the idea of a Military Union was probably supported by a similar number of the officers present. Given that the bureau did not manage to organize its own conference to establish the union formally, it is difficult to find substance in a larger figure. To be sure, larger numbers would have broadly supported the union's aims, but that did not mean that they would become members. Membership levels are hard to establish for any organization during this period, especially in the military, as even the established unions did not keep lists. But the Military Union clearly only enjoyed a fraction of the level of support of the Union of Officers at this stage ${ }^{51}$ let alone the mass participation in soldiers' committees and soviets.

The offensive provided other opportunities to promote the union. On 14 June, the union published an appeal in the press urging the army to fight to a victorious conclusion. Defeat would result in a victory for Germans and reactionaries. ${ }^{52}$ On 26 June, the bureau asked Stavka to distribute 600,000 copies of another appeal to the troops and a million copies of the union's proposed programme. Appreciating the value of anything that might bolster the fighting strength of the military, Stavka agreed, but demurred on the quantities. Instead, 1,000 copies of each piece would be sent to the staffs of every army for further distribution. ${ }^{53}$ The bureau also sent thirty copies of the appeal and the programme to the executive committee of each front (the main soldiers' body), asking each committee to distribute the material. ${ }^{54}$ The bureau then sent out additional material as required, such as the 40,000 copies of the programme and 25,000 copies of the appeal dispatched to Omsk Military Region on 4 July. ${ }^{55}$

This material was far more detailed than it was possible to publish in the regular press. The programme outlined the union's vision of a strong, disciplined military with unity between 
officers and soldiers. It was forceful in its condemnation of the Germans, its support for the allies and its commitment to the war effort. An offensive promised to facilitate a quick end to the war, as well as freeing territory occupied by the Germans. The union also promised to defend the rights of all personnel. The appeal reiterated the need to fight, albeit with greater use of patriotic language, stressing the fate of the motherland and asking whether Russians had really scrapped Tsarism to become German slaves. The Military Union, the appeal promised, would take the practical and educational steps needed to build the unity and discipline required to achieve success, and to prove that honour and bravery remained in the army. ${ }^{56}$

In a memo on 29 June, the bureau seemed satisfied with its progress. Its workload was increasing daily, as it was receiving numerous requests for material on the union and on how to become members, as well as plenty of volunteers for battalions of death. Four to five members were permanently absent, either in Petrograd lobbying for a conference, in Moscow printing agitational material, or spreading the union's ideals at the front. The bureau agreed to send an additional five officers and ten soldiers on a tour of the front to spread awareness of the union, whilst highlighting the need for help to cope with the workload. ${ }^{57}$ The bureau commissioned reports on a range of pertinent issues, including the political allegiances of soldiers, the impact of democratization on the army and the role of political bodies in the military. There were plans to produce material on other topics to utilize in educational work, such as political history, revolutions and the women's question. ${ }^{58}$

There is little doubt that the bureau was galvanized by the offensive and its experiences should force historians to place caveats on the traditional picture of the military in 1917 . To be sure, the bureau's passionate defence of the war placed it at odds with the majority of its potential supporters. Most soldiers wanted an end to the war. They had reluctantly accepted calls for a defensive war from the government after the February Revolution and their attitudes hardened 
during the June Offensive. Soldiers ignored orders to advance and started to demand peace at any cost. Fraternization with the Germans and outright rebellion became more frequent. ${ }^{59}$ The offensive turned into a debacle, the government lost much of its remaining support, and the Bolsheviks' vocal promises of peace became more attractive.

However, the bureau's experiences demonstrate that a sizeable number of soldiers did not subscribe to the above views, instead adopting a patriotic stance towards the war effort. Similarly, a recent study of women's revolutionary battalions has noted that they attracted numerous volunteers from all social and educational backgrounds. This, it was argued, proved that 1917 was not dominated by class conflict and war weariness for all Russians and that a commitment to the country's defence crossed class lines. Furthermore, recruitment continued after the disastrous offensive proving that the revolution could foster some degree of patriotism. ${ }^{60}$

Patriotism, therefore, remained stronger within sections of society and the military than historians have been inclined to accept. Traditional views of patriotism declining prior to the war have already been contested by those who have argued that it simply took different forms. From anti-German riots to 'economic nationalism' targeting the livelihoods of ethnic minorities, some forms of patriotism remained strong before 1917. Moreover, the increasing criticism of the tsarist regime utilized patriotic discourse with widespread accusations of treachery and German links. ${ }^{61}$ Indeed, patriotism has often been a driving force of revolution. Hobsbawm noted how in the American, Dutch and French revolutions, 'patriots' were those who demonstrated their love of their country by supporting revolution to build a stronger country. ${ }^{62}$

Similar sentiments were present in Russia in 1917 where the revolution was seen as a national and patriotic revolution to rebuild Russia. It was not so much conflicts between classes that caused revolution, but a conflict between the whole of society and a corrupt regime. ${ }^{63}$ It was also far from uncommon, particularly in spring 1917, to hear people argue that an offensive 
would prove that February was a national revolution rather than just a revolt against the old regime or, at the very least, that an offensive would ensure the future of Russia, preventing a victory for the Kaiser who may then restore the monarchy to Russia. ${ }^{64}$ These voices have been drowned out in the historical record by the more numerous and louder demands for peace, but they were present. The numbers joining revolutionary battalions provide evidence of this and the bureau's experiences illustrate that class conflict between officers and soldiers was not the only division weakening the military in 1917. It was joined by an equally deep chasm between those supporting the war and those opposing it, which cut across class divisions.

Ultimately, though, the determination to promote the war, alongside demands for 'iron discipline' to forge a strong military, was a huge risk. The union believed that they could change soldiers' minds and foster belief in the war, but after three years of fighting, this was a thankless task. Moreover, its pro-war stance led many soldiers to associate it with 'counter-revolutionary' conservative and liberal groups, who also supported the war. These groups usually advocated obtaining financial and territorial gains from the war. The bureau said nothing on this issue, but all pro-war views tended to be lumped together in soldiers' minds. The bureau was realistic, recognizing that they needed to develop the 'civil self-awareness' of soldiers to combat rampant passivism. In the meantime, further chaos at the front might convince the authorities of the importance of the union's message and, hence, the potential value of the union. ${ }^{65}$ But whilst its activities were gathering pace by mid-1917, to be more influential, it needed to hold a conference, establish a legal union (with a clear base of support to provide a mandate), and promote its views more effectively, preferably through a regular newspaper. 
On 18 July 1917, General L. G. Kornilov replaced Brusilov as Commander-in-Chief as the latter took the blame for the failed offensive. Kornilov had been Brusilov's successor as Commander of the South-West Front and had emerged as a strong advocate of re-establishing order in the military. Although not entirely opposed to soldiers' committees, Kornilov had campaigned successfully for the reintroduction of the death penalty at the front, and introduced measures to curb Bolshevik agitation and agrarian unrest in the areas under his control. His appointment to the highest post seemed to demonstrate that Kerenskii, now the head of the government, realised that only greater discipline and order could prevent a disastrous defeat. Kornilov's appointment was greeted enthusiastically by officers' unions, the propertied classes and other conservative groups, but viewed suspiciously by soldiers and lower social classes. ${ }^{66}$

On 26 July, the bureau sent a report to Kornilov, no doubt to curry favour, which outlined its achievements since May. Despite the continued failure to obtain permission for a conference (due to ongoing military conditions), the bureau promoted its role in creating battalions of death and claimed that it had circulated over 3 million brochures, appeals and flyers. More notably, it highlighted its plans to publish a newspaper from August onwards. ${ }^{67}$ The bureau realized that it needed a substantial mouthpiece for its views if it was going to influence opinion, and publishing a newspaper was seen as an essential move by all unions, committees and like-minded bodies during 1917. It was the primary means of publicizing an organization's views and could have a significant impact. The Union of Officers, for example, observed a flurry of interest in their union after the publication of every issue of their newspaper. ${ }^{68}$ However, the practicalities of publishing - obtaining a printing press, sourcing sufficient supplies of paper, acquiring experienced staff were problematic for all groups and the bureau was no exception.

The intention was to produce a socio-political newspaper to distribute across the military and Russian society. It would promote a strong military, but focus on a range of issues to make it 
attractive to wider society; for example, using links to Stavka to provide foreign news. In early June, the bureau dispatched a representative to Petrograd to acquire machinery. ${ }^{69}$ On 10 July, Brusilov granted 150,000 rubles towards a newspaper and permitted it to use the printing press at Stavka. ${ }^{70}$ By the end of July, the bureau had created a network of correspondents across the military, alongside socialist and liberal journalists and politicians. The latter ranged from the anarchist, Prince P. A. Kropotkin, and the socialists, E. K. Breshko-Breshkovskaia, G. V. Plekhanov and V. I. Zasulich, to the liberals, P. B. Struve and Prince E. N. Trubetskoi. This diversity, the bureau argued, would emphasize the newspaper's non-party stance. Brusilov's departure forced the bureau to renew its request for money and access to the printing press, as well as permission to transfer staff to Stavka. This was granted by Kornilov in early August. By 19 August, over two months after preparations started, the bureau had the press, paper supplies and publishable material. It only needed a few more workers and the first issue of the newspaper, Son of the Fatherland [Syn otechestva], would be ready. ${ }^{71}$

In addition, the bureau, encouraged by Kornilov's appointment, made a new attempt to hold a conference. On 7 August, the bureau asked Kornilov for permission to hold a conference on 18-20 August of all those organizations supporting the war effort and a strong military, alongside state and public figures. By promoting unity and exploring ways of improving the military, the bureau believed that this conference could be an alternative to a general military conference and a means of formally sanctioning a military union. The bureau envisaged inviting 30-40 people. Delegates from Stavka and the government, and several politicians (including Kropotkin, Plekhanov, and a leader of the nobility, A. D. Samarin), would join representatives from the Cossacks, Union of Officers, Union of George Cavaliers, Military League, and unions representing doctors, clergy, the navy, and other military personnel. There would also be a concurrent mass promotion of the union through leaflets and appeals. ${ }^{72}$ 
As news of the proposed conference spread, it prompted a flurry of complaints from army committees. The committee of the $8^{\text {th }}$ Army noted that conferences were currently forbidden at the front and accused the Military Union of taking advantage of its position at Stavka to organize a meeting of reactionary groups. This was counter-revolutionary and the committee urged people not to participate and called for the conference to be forbidden. ${ }^{73}$ Other committees sent similar complaints. ${ }^{74}$ In the face of these protests, the Ministry of War reiterated on 14 August that no conferences were permitted involving anyone at the front and, on the basis of these instructions, Kornilov refused permission. ${ }^{75}$

Although Kornilov's hands were tied by the government's decision, it does seem justified to believe that successive commanders-in-chief could have supported the idea of a military union far more than they did. Alekseev had noted the 'deep gulf' between officers and soldiers in his speech on 7 May to the congress of officers at Stavka and talked rhetorically about the need to forge both groups 'into a common union', yet did not intervene in the deadlock over plans to form an real union devoted to this aim. ${ }^{76}$

Brusilov supported battalions of death, permitted the bureau's representatives to tour the front and sanctioned plans to publish a newspaper. He did speak out to support officers and their right to mobilize, but he opposed the Union of Officers' more strident demands, and their obsession with honour and the impregnable position of the officer. ${ }^{77}$ The union's president, Novosil'tsev, feared that it would be abolished as Brusilov felt that an officers' union was illtimed and that a general military union was far more relevant. ${ }^{78}$ Yet, if Brusilov had supported the bureau whole-heartedly, concerns over the need for a conference to legally sanction the union could have been resolved and quicker progress made on publishing a newspaper.

Officers' organizations were in the ascendancy under Kornilov. On 19 July, the Chief of Staff, General A. S. Lukomskii, urged Kerenskii to meet delegates from the Union of Officers as 
it represented thousands of officers and advocated desirable policies. ${ }^{79}$ Stavka started to intervene to support the Union of Officers' policies. The most obvious example was the attempt to blacklist those officers seen as unreliable 'demagogues' (usually those associated with socialist parties, particularly the Bolsheviks). Many officers opposed this policy, as did government officials, arguing that the union was not qualified to judge political affiliations or to order officers to be blacklisted. ${ }^{80}$ Yet, Stavka sent telegrams stating its support for the policy to recalcitrant local commanders, ordering them to provide lists of suspect officers as the union requested. ${ }^{81}$

On 29 July, the Military Union was included, alongside the Union of Officers, Union of George Cavaliers and the staffs of all fronts, in Stavka's plans to establish a commission to work on new laws covering discipline, internal service and other related issues, with Stavka asking for three representatives from the bureau, an officer and two soldiers. ${ }^{82}$ Kornilov also continued Stavka's support for publishing a newspaper but, generally, Kornilov's Stavka did not seem to be convinced that a military union could be effective or was even desirable.

The failure to obtain permission for an August conference prompted the bureau to rename itself the Temporary Committee of the All-Russian Military Union on 19 August, finalize the regulations and distribute them across the military. After months in limbo, the bureau decided move ahead and establish the union formally, even if its leadership remained 'temporary' prior to a conference. In reality, nothing changed. On the one hand, the union still lacked the mandate that came with being able to prove a certain level of support. On the other, it could do little but to continue promoting the union through lectures, agitation and publications. The bureau feared that its lack of favour stemmed from Stavka's belief that the Military Union was insufficiently distinct from the Union of Officers (something that the soldiers in the bureau found absurd) and even threatened to undermine the latter. ${ }^{83}$ 
More dangerously, soldiers also failed to discern a significant difference. Officers had always been regarded suspiciously by soldiers, but by August, there was a pervasive fear that officers' unions were organizing a counter-revolution. These fears were exacerbated by a popular belief that a conservative 'movement' was emerging from officers, industrialists, landowners, and conservative and liberal politicians. By this stage, these groups were pressing for a stronger government in Russia, as demanded at a meeting of their representatives, the Congress of Public Figures, on 8-10 August. They also formed a vocal bloc at the Moscow State Conference on 1215 August, a national gathering representing all groups, which was designed to bolster support for the government. Similar calls emerged from the All-Russian Sobor of the Orthodox Church, whose first session started on 15 August and lasted to 9 December. $^{84}$

There is no evidence to suggest that the bureau was involved. It obtained two seats at the Moscow Conference, ${ }^{85}$ but all social and political groups were present, and there is no indication that its delegates were aligned with the conservative bloc. The bureau was also invited to elect one member of a fifteen-man delegation from the active army to the Sobor, but, again, there is no evidence of suspect activities. ${ }^{86}$ The Union of Officers wrote to the Military Union on 3 August asking for someone to report to it on the bureau's activities and suggesting future cooperation. Yet the Military Union had not been invited to a meeting of twelve conservative military organizations a few days earlier, which had discussed forming a joint Union of National Defence. Similarly, an outline of the Union of Officers' activities at this time made no mention of the Military Union when discussing links being forged with other military groups. ${ }^{87}$

In part, this is hardly surprising. After all, the Military Union had emerged in May in direct opposition to plans to create the Union of Officers. Moreover, there were strong disagreements over some policies - most notably, revolutionary battalions. On 11 June 1917, the Union of Officers argued that these battalions were dangerous and harmful; recruiting civilians 
could bring Bolshevism to the front, whilst the whole army needed to be 'revolutionary'. ${ }^{88}$ That said, the Military League supported the idea and this did not prevent it from working with the Union of Officers. The Military Union's pro-war stance made some relationship with officers' groups and other conservative bodies seem natural, especially as alliances were one of the few ways that these minority groups could wield greater political influence. No doubt the bureau feared that any links would undermine their support among soldiers, but the reactions to the proposed August conference make it clear that soldiers were already suspicious. The Petrograd Soviet's national newspaper, Izvestiia, publicly classified the Military Union as 'counterrevolutionary' in mid-August. ${ }^{89}$

\section{V}

The growing crisis in Russia culminated on 27-31 August in the Kornilov Revolt. The weeks preceding it saw tensions escalate between Kornilov and Kerenskii, exacerbated by the German advance towards Petrograd and rumours of an imminent Bolshevik coup. For Kornilov, the Soviet was the root of the problems and he was determined to deal with it. He favoured a new, more authoritarian government, preferably with a leading role for him. Kerenskii was open to suggestions, but wanted to retain his position and restrict the Soviet's authority, rather than eradicate it. Both feared the other's ambitions, but compromise appeared possible. Kornilov's initial demands seemed to be accepted and Kerenskii agreed to have more troops in Petrograd to suppress a Bolshevik revolt. On 27 August, however, a garbled telex conversation with Kornilov fuelled Kerenskii's suspicions and he dismissed Kornilov as Commander-in-Chief. Kornilov refused to leave, claiming government betrayal, and troops loyal to him advanced on Petrograd. Local soviets mobilized, convincing the soldiers that they were part of a counter-revolutionary 
coup rather than acting to save the government, as they had been told. By 31 August, the revolt had disintegrated, and Kornilov and a number close associates were arrested. ${ }^{90}$

Unlike the Union of Officers and other conservative groups, ${ }^{91}$ the bureau condemned the revolt, but not without discord. According to the testimony of N. I. Minin, a soldier and bureau member, given on 2 September to a commission investigating the revolt, news of events emerged on 28 August. ${ }^{92}$ This prompted the bureau to meet in the morning to formulate a plan of action. The officers wanted to support Kornilov, but the soldiers did not. In the end, the bureau called for calm, unsure whether to believe all of the rumours circulating. In the evening, the soldiers in the bureau reconvened and this time took a firm resolution to support the Provisional Government. They sent an appeal directly to Petrograd, which declared that Kornilov had no right to refuse a legal order from the government and an armed uprising was state treason. They offered to mobilize battalions of death to help suppress the revolt. ${ }^{93}$ Minin does not say whether the officers in the bureau agreed. He noted that they indicated to the bureau that leaders of the Union of Officers were involved in events and that the plan was to make Kornilov a dictator, which the soldiers found disagreeable. Minin even participated in a temporary committee established by Mogilev's soviet to oppose the revolt. ${ }^{94}$

Despite its decision to denounce Kornilov, the bureau was still compromised. Captain A. P. Bragin, who had edited Stavka's military newspaper and was involved in the plans to launch the union's newspaper, used his access to Stavka's printing press to publish Kornilov's appeal. A bureau member, Colonel K. V. Sakharov, used machinery controlled by his department in Stavka for the same purpose. Minin condemned their actions and contrasted their support for the revolt with the bureau's opposition. He also noted (justifiably) that Sakharov rarely participated in the bureau's activities. Bragin and Sakharov did not deny the charges, although they did claim to be following orders. ${ }^{95}$ Yet their actions forced the bureau to defend itself amid the recriminations 
that swept across Russia in the aftermath of the revolt. The bureau decided to participate in the investigations into the revolt to stress its own non-involvement. Similarly, on 3 September, it distributed a telegram across the military and the press reiterating its support for the government and condemnation of Kornilov, reminding readers of its telegram of 28 August. $^{96}$

The Military Union was not directly affected by the clampdown on military organizations after the revolt, but events did set back its activities. Bragin, now under arrest, had been gathering staff for the newspaper, as well as acquiring machinery and sourcing supplies of paper, spending around 60,000 rubles of the original 150,000 . The bureau claimed that their plans were back on track in a letter to the Chief of Staff on 12 September, but the arrival of General N. N. Dukhonin as the new Commander-in-Chief required yet another set of permissions regarding finance, printing presses and personnel. ${ }^{97}$

Initially, permission was granted, or at least the bureau was confident that it would be, as the seemingly endless preparations continued. ${ }^{98}$ But, soon afterwards, the printing press granted to them was reallocated to create an official newspaper for Stavka. On 27 September, the bureau claimed that army committees had complained that Stavka was favouring their organization over others. It resolved to send a delegation to Dukhonin protesting that the decision ended months of hard work, wasted the money already spent and undermined their activities. The bureau was also convinced that its plans offered an independent newspaper, whereas Stavka's organ would be its own mouthpiece and would be ignored as such by the soldiers. ${ }^{99}$ Stavka, though, was sensitive to accusations of favouring undesirable organizations in the aftermath of the revolt.

In a meeting on 3 October 1917, the bureau seemed resigned to ending its plans to publish a newspaper. ${ }^{100}$ But even winding down the paper seemed to take an inordinate amount of time, especially as futile attempts to obtain an alternative printing press continued. A meeting on 15 November complained that the whole affair - primarily the costs incurred - had still not been 
resolved and related issues reappeared throughout November. There was a struggle, for example, to sell the stocks of paper that had been purchased. ${ }^{101}$

The Military Union, unlike conservative groups, was represented at the next national assembly, the Democratic Conference in Moscow on 14-19 September, ${ }^{102}$ which included socialist parties, soviets, trade unions, and other popularly-elected bodies. But the conference failed to have any impact. ${ }^{103}$ The Kornilov Revolt seemed to prove that popular fears of counterrevolution were justified and it encouraged people to seek more radical ways of realizing their ambitions. The Bolsheviks gained majorities in the soviets in Petrograd and Moscow in late August and early September respectively, and their demands for 'All Power to the Soviets' and 'Peace, Bread and Land' struck a chord with ordinary Russians, especially soldiers. Kerenskii made a final attempt to bolster support with the Provisional Council of the Russian Republic (Preparliament) in Petrograd on 7-25 October. It had the same aim as the Moscow Conference; namely, to strengthen a weak government by bringing groups of various political hues together. Soldiers from the front received 25 seats, although it is unclear whether the union was represented. ${ }^{104}$ Growing divisions, though, meant that the Preparliament was also doomed to fail. The bureau focused on preparing for the forthcoming elections to the Constituent Assembly (scheduled for November), having already sought permission to publish and distribute brochures on the subject, ${ }^{105}$ but, otherwise, it made little headway prior to the October Revolution.

The bureau opposed the Bolsheviks' seizure of power, declaring on 27 October that attempts by 'individual political parties to impose their will on the people of Russia through a revolt were criminal'. The Germans were advancing steadily towards Petrograd by this stage and the bureau argued that an uprising would encourage anarchy in Russia, weaken the 'revolutionary army' further and pave the way for German success. It even reiterated rumours that the Germans were behind events through money allegedly provided to the Bolsheviks. The uprising also 
jeopardized the Constituent Assembly, the ultimate expression of the people's will. The bureau finished by arguing that the Provisional Government and the Soviet had been strengthening freedom and the achievements of the revolution. ${ }^{106}$

The union continued operating, but given that there was still no conference and the plans for a newspaper had ended, it is difficult to see it justifying its existence. The bureau recognized the need to reinvigorate the union and restructured its administration in late October. Previously, there had been three departments covering general issues, agitation and battalions of death. Now, six departments were created. Agitation and battalions of death gained additional departments overseeing the finances involved in each enterprise, with the final two departments focusing on general finances, and frontline and economic issues. ${ }^{107}$ It is questionable whether this was a positive move to enable the bureau to better focus on its core activities - agitation and the battalions of death - or a reaction to the difficult circumstances faced by all organizations after the October Revolution. In terms of finance, for instance, the bureau admitted problems on 12 November. Banks were only paying out 1,000 rubles a day due to the turbulent events, leaving the bureau reliant on selling the paper purchased for the newspaper. ${ }^{108}$

Moreover, the disintegration of the military intensified after the Bolsheviks announced their intention to end the war in the Decree on Peace on 26 October. One study estimated that whilst there were 90 revolutionary battalions on 21 October, only six remained on 13 November. ${ }^{109}$ The bureau supported plans in early November to unite shock units, revolutionary battalions and battalions of death, and organize a meeting of various representatives, but to no avail. ${ }^{110}$ The all of these units were disbanded officially on 9 December by the Bolshevik Commander-in-Chief, Ensign N. V. Krylenko, amid fears that they hindered demobilization and had been involved in resistance or counter-revolutionary activities. ${ }^{111}$ 
As one bureau member noted on 5 November, political events demonstrated that the masses did not sympathize with the union's aims and he argued that the union's continued existence was pointless. ${ }^{112}$ His colleagues did not agree, but evidence from the union stops at the end of November. Soviet archivists noted that the union was 'liquidated' in December 1917.

VI

Overall, the record of the All-Russian Military Union from May to December 1917 is far from impressive. All military organizations struggled in the face of a mass soldiers' movement focused overwhelmingly on soldiers' committees, but the union was less effective than most. It was never sanctioned by a conference and thus never recruited members officially. This made it difficult for the union to prove that it spoke for a section of the military. It failed to publish a newspaper, which many groups managed, leaving it struggling to promote its views. Its only success came through its promotion of revolutionary battalions. Not all of this was the union's fault, especially its inability to hold a conference, but it explains why historians have ignored the union.

Nevertheless, the union demonstrates (along with revolutionary battalions) that a vocal group of soldiers was supportive of the war effort and the government. Thus, whilst historians often talk about divisions between lower classes and propertied groups during the revolutionary period, there were also sizeable differences within these groups. This can also be seen in the countryside where some peasants, particularly the more prosperous, wanted to defend the private ownership of land during 1917 against the demands of the vast majority for land redistribution. Many joined the All-Russian Union of Landowners, but others were uncomfortable as they felt that this body was dominated by noble landowners and established their own peasant unions to defend landownership. ${ }^{113}$ Similarly, although soldiers joined groups led by officers, such as the 
Union of George Cavaliers, those behind the Military Union believed that there was room for a pro-war organization dominated by soldiers. Opinions did become more polarized as 1917 progressed, but within social groups as well as between them.

Nevertheless, class divisions remained central. The dominant belief was that democracy should solely benefit the lower social classes - soldiers, workers and peasants - and that the revolution should progress on their terms. When most soldiers talked of sympathetic officers working hand-in-hand with the soldiers, it was in terms of officers working within soldiers' institutions, rather than any type of general union. Those soldiers within the Military Union did not agree, but these divisions were still reflected within the union; for example, in the opposite reactions of the soldiers and officers in the bureau to the Kornilov Revolt, and in the reluctance of the union to forge alliances with conservative officers' groups.

These divisions were exacerbated from above. Despite the fact that a unified military was in the interests of the war effort, which all of the main authorities - the government, the Soviet and Stavka - supported to a greater or lesser degree, none supported the Military Union as much as they could have done. Instead, all favoured organizations that were more divisive, whether soldiers' committees, soviets of officers' deputies, and the Union of Socialists of the People's Army, or the Union of Officers and Union of George Cavaliers. Stavka was at its most favourable under Brusilov, but it still did not provide much active support. This may have been an attempt to remain neutral, but given that the union aimed to unite all groups in the military, eschewed party politics and supported the war, it could have only helped to fulfil Stavka's own objectives.

In retrospect, the union's aim to foster enthusiasm for the war seems futile given the widespread desire for peace. The union probably would not have achieved anything even if it had held a conference and published a newspaper. After all, other groups did both and still failed to influence the popular mood. What is notable, however, just as it is for other military 
organizations, as well as unions and societies across Russia during 1917, is how those involved in the Military Union did not believe that their activities were futile.

From February 1917 onwards, unions and societies proliferated across Russia. In part, this was the result of long-standing desires released by the freedom obtained after the February Revolution. In part, though, it was because the nature of politics after February encouraged such actions. As the name suggested, the government was provisional, ruling until elections were held to form a Constituent Assembly, which would decide Russia's political future. In the meantime, particularly as these elections were repeatedly delayed, the government ensured that all important political and social groups were represented in national assemblies and committees, irrespective of their level of support. ${ }^{114}$ Those involved in the Military Union knew that in such an environment, despite mass demands for peace, they could express their views and possibly wield some influence. They were not completely disappointed; they helped create battalions of death, they gained representation on committees at Stavka discussing new laws for the military and they were present at nationwide conferences. Thus, the union's activities highlight the nature of politics in 1917 as well as the complex divisions within Russia’s military and society. 
${ }^{1}$ The best studies of the military in 1917 are M. Frenkin, Russkaia armiia i revoliutsiia 19171918 (Munich, 1978); and A. Wildman, The End of the Russian Imperial Army (2 vols., Princeton, 1980-7).

${ }^{2}$ R. Browder and A. Kerensky (eds.), The Russian Provisional Government. Documents (3 vols., Stanford, 1961), II, pp. 848-9.

${ }^{3}$ As well as Frenkin and Wildman, see A. Andreev, Soldatskie massy garnizonov Russkoi armii v oktiabr'skoi revoliutsii (Moscow, 1975); L. Gavrilov, Soldatskie komitety v oktiabr'skoi revoliutsii (deistvuiushchaia armiia) (Moscow, 1983); and V. Miller, Soldatskie komitety Russkoi armii v 1917 godu (Moscow, 1974).

${ }^{4}$ See M. Mayzel, Generals and Revolutionaries: The Russian General Staff during the Revolution (Osnabruck, 1979); and S. Volkov, Tragediia Russkogo ofitserstva (Moscow, 1999). ${ }^{5}$ On the mobilization of officers, see I. Grebenkin, Russkii ofitser $v$ gody mirovoi voiny $i$ revoliutsii, 1914-1918gg. (Riazan', 2010); V. Polikarpov, Voennaia kontrrevoliutsiia v Rossii, 1905-1917 (Moscow, 1990); and M. Rendle, Defenders of the Motherland: The Tsarist Elite in Revolutionary Russia (Oxford, 2010).

${ }^{6}$ Rendle, Defenders, pp. 144-52.

${ }^{7}$ Frenkin, Russkaia armiia, pp. 85, 102-3; Miller, Soldatskie komitety, pp. 111, 119.

${ }^{8}$ I know of only one study with more than a passing reference to the union, but even this focuses primarily on another issue; D. Ivanov, “"Rozhdennyi na zare svobody - za nee umret...” Chasti smerti v russkoi armii 1917', in Voennyi sbornik. Stat'i i publikatsii po Rossiiskoi voennoi istorii do 1917 (Moscow, 2004), pp. 113-23.

${ }^{9}$ For e.g., Wildman, End, I, p. xv. 
${ }^{10}$ Telegram to officers, 17 April 1917, Rossiiskii gosudarstvennyi voenno-istoricheskii arkhiv (RGVIA), f. 391, op. 2, d. 136, 11. 6-12; and Lebedev's account in Delo generala L. G. Kornilova (2 vols., Moscow, 2003), II, p. 415.

${ }^{11}$ The soldiers wrote a balanced account of proceedings. Copies are in RGVIA, f. 2003, op. 14, d. 4, 11. 1-6, and Gosudarstvennyi arkhiv Rossiiskoi Federatsii (GARF), f. 4018, op. 1, d. 4, 11. 1-6.

12 Soldiers' report on the congress, undated, RGVIA, f. 2003, op. 14, d. 4, 11. 1-1ob.

${ }^{13}$ Soldiers' report, RGVIA, f. 2003, op. 14, d. 4, 1. 3.

${ }^{14}$ Soldiers' report, RGVIA, f. 2003, op. 14, d. 4, 1. 3ob.

${ }^{15}$ Soldiers' report, RGVIA, f. 2003, op. 14, d. 4, 11. 4-5ob.

${ }^{16}$ Novosil'tsev's memoir account of the congress is in GARF, f. 6422, op. 1, d. 1, 11. 137-153.

${ }^{17}$ Six telegrams by Novosil'tsev and Captain V. E. Rozhenko reporting on the officers' congress, 15-22 May 1917, RGVIA, f. 366, op. 1, d. 16, 11. 108-18, 139-52.

${ }^{18}$ Report on the May congress from the chief committee of the Union of Officers for widespread distribution, 24 May 1917, GARF, f. 1780, op. 1, d. 71, 1. 53ob.

${ }^{19}$ Soldiers' report, RGVIA, f. 2003, op. 14, d. 4, 11. 6-7.

${ }^{20}$ Letter from the soldiers' committee of the $129^{\text {th }}$ Bessarabian infantry to the Central Executive Committee of the Petrograd Soviet, received on 5 August 1917, in M. Steinberg, Voices of Revolution, 1917 (New Haven, 2001), p. 207.

${ }^{21}$ Report from the bureau to the Commander-in-Chief, 26 July 1917, RGVIA, f. 2003, op. 1, d. 1782, 1. 79ob.

${ }^{22}$ Programme of the All-Russian Military Union, undated, RGVIA, f. 2003, op. 1, d. 1782, 11. 2828 ob. 
${ }^{23}$ Novosil'tsev's memoirs, GARF, f. 6422, op. 1, d. 1, 1l. 154ob, 156; Report from the bureau to the Commander-in-Chief, 26 July 1917, RGVIA, f. 2003, op. 1, d. 1782, 1. 79ob.

${ }^{24}$ Polikarpov, Voennaia, pp. 144-71; Rendle, Defenders, pp. 129-32.

${ }^{25}$ Rendle, Defenders, pp. 117-20.

${ }^{26}$ Soldiers' report, RGVIA, f. 2003, op. 14, d. 4, 1l. 3ob, 4ob.

${ }^{27}$ Report from the bureau to the Commander-in-Chief, 26 July 1917, RGVIA, f. 2003, op. 1, d. 1782, 1. 79ob.

${ }^{28}$ RGVIA, f. 366, op. 2, d. 56, 1l. 8-8ob (appeal of the first general assembly of officers and soldiers in Moscow region, undated), 12-12ob (protocols of a meeting of the Soviet of Officers' Deputies in Moscow Military Region, 7 March 1917).

${ }^{29}$ For e.g., see the regulations of the organization of officers in the $12^{\text {th }}$ Army, undated, RGVIA, f. 366 , op. 2 , d. $124,1.3$.

${ }^{30}$ Two appeals by the bureau for support for a military union, undated, RGVIA, f. 2014, op. 1, d. 8, 11. 2-7, 18-18ob.

${ }^{31}$ Resolution of an assembly of members of the initiating group of the All-Russian Military Union, 30 May 1917, RGVIA, f. 366, op. 2, d. 124, 1l. 27-27ob.

${ }^{32}$ Browder and Kerensky, Russian Provisional Government, I, pp. 226-7. See also A. Tumanova, Obshchestvennye organizatsii i Russkaia publika v nachale XX veka (Moscow, 2008), pp. 281-8. ${ }^{33}$ See the concise discussion in R. Wade, The Russian Revolution, 1917 ( $^{\text {nd }}$ edition, Cambridge, 2005), pp. 175-83.

${ }^{34}$ Documents on shock units and revolutionary battalions are in N. Kakurin, ed., Razlozhenie armii v 1917 godu (Moscow-Leningrad, 1925), pp. 64-77; N. Ross, 'Popytka sozdaniia russkoi revoliutsionnoi armii (mart-iiun’1917g.), Novyi chasovoi, 1 (1994), pp. 75-87; and N. Ross, 
'Udarnye chasti v russkoi armii (vesna i leto 1917g.), Novyi chasovoi, 2 (1994), pp. 130-9. See also R. Abiniakin, Ofitserskii korpus Dobrovol'cheskoi armii: Sotsial'nyi sostav, mirovozzrenie. 1917-1920gg. (Orel, 2005), pp. 28-44; Grebenkin, Russkii ofitser, pp. 230-52; S. Solntseva, 'Udarnye formirovaniia Russkoi armii v 1917 godu', Otechestvennaia istoriia, 2 (2007), pp. 4759; and Wildman, End, II, pp. 79-81.

${ }^{35}$ Ross, 'Udarnye’, p. 133.

${ }^{36}$ L. Stoff, They Fought for the Motherland: Russia's Women Soldiers in World War I and the Revolution (Lawrence, 2006), pp. 61-9, 74-7.

${ }^{37}$ Ivanov, 'Rozhdennyi', pp. 113-14.

${ }^{38}$ Ross, 'Udarnye', p. 135.

${ }^{39}$ Ross, 'Udarnye', pp. 133-4.

${ }^{40}$ A. Kibovskii, 'Revoliutsiei prizvannye: udarnye revoliutsionnye batal'ony iz volunterov tyla. 1917', Tseikhgauz, 8 (2/1998), p. 35.

${ }^{41}$ Letter from the chief committee of the Union of Officers to the Commander-in Chief, 11 June 1917, RGVIA, f. 2003, op. 1, d. 1782, 11. 31-32ob.

${ }^{42}$ Various correspondence from the Military League to the Commander-in-Chief, June-July 1917, GARF, f. 1780, op. 1, d. 78, 11. 24-28. See also A. Maslakov, 'Predshestvenniki dobrovol'cheskoi armii', Belaia gvardiia, 2 (1998), 59-68.

${ }^{43}$ Telegram from the bureau to the Commander-in-Chief and chiefs of staff of all the fronts, 8 August 1917, RGVIA, f. 2014, op. 1, d. 16, 1. 158.

${ }^{44}$ RGVIA, f. 2014, op. 1, d. 3, 11. 72ob (letter by V. F. Chepelkin, a bureau member, July 1917), 105 (resolution of the bureau, 28 August 1917); d. 16, 11. 339 (telegram from the bureau to the 
Chief of Staff at Stavka, 12 September 1917), 442ob (telegram from the bureau to the Chief of Staff, 30 October 1917).

${ }^{45}$ Report from the bureau to the Commander-in-Chief, 26 July 1917, RGVIA, f. 2003, op. 1, d. 1782, 1. 80.

${ }^{46}$ M. Stockdale, "“My Death for the Motherland is Happiness": Women, Patriotism, and Soldiering in Russia's Great War, 1914-1917', American Historical Review, 109, 1 (2004), p. 92;

Ross, 'Udarnye', pp. 135-7.

${ }^{47}$ Abiniakin, Ofitserskii, p. 187; Solntseva, 'Udarnye', p. 50.

${ }^{48}$ Ivanov, 'Rozhdennyi', p. 114.

${ }^{49}$ See RGVIA, f. 2014 (Temporary Committee of the All-Russian Military Union).

50 'Citizens of the Military' appeal by the bureau, 7 June 1917, RGVIA, f. 2003, op. 1, d. 1782, 1. 29.

${ }^{51}$ Rendle, Defenders, pp. 142-3.

${ }^{52}$ Ivestiia, No. 64, 14 June 1917.

${ }^{53}$ Correspondence from the bureau to the Quartermaster General at Stavka, and from him to the Chief of Staff, 26-27 June 1917, RGVIA, f. 2003, op. 1, d. 1782, 11. 25-26.

${ }^{54}$ Note from the bureau's secretary, undated, RGVIA, f. 2014, op. 1, d. 8, 1. 44.

${ }^{55}$ Unsigned letter to Omsk Military Region, 4 July 1917, RGVIA, f. 2014, op. 1, d. 16, 1. 91.

${ }^{56}$ RGVIA, f. 2003, op. 1, d. 1782, 11. 27-28ob (programme of the All-Russian Military Union, undated ), 29-29ob (appeal ‘Citizens of the Military’, 7 June 1917).

${ }^{57}$ Memo to all members of bureau, June 1917, RGVIA, f. 2014, op. 1, d. 16, 11. 74-75.

${ }^{58}$ Various reports, undated, RGVIA, f. 2014, op. 1, d. 225, 11. 2-14. 
${ }^{59}$ Numerous examples have been collated in Antivoennye vystupleniia na Russkom fronte v 1917 godu glazami sovremennikov (vospominaniia, dokumenty, kommentarii) (Moscow, 2010).

${ }^{60}$ Stockdale, 'My Death', pp. 81, 96, 108, 111. These issues are also discussed in Stoff, They Fought, pp. 78-80, 120-1, 127-8, 136, 206-10.

${ }^{61}$ See W. Fuller, The Foe Within: Fantasies of Treason and the End of Imperial Russia (Ithaca, 2006); H. Jahn, Patriotic Culture in Russia during World War I (Ithaca, 1995); E. Lohr, Nationalizing the Russian Empire: The Campaign Against Enemy Aliens during World War I (Cambridge, MA., 2003); and B. Kolonitskii, “"Tragicheskaia erotica”: Obrazy imperatorskoi sem ’i v gody pervoi mirovoi voiny (Moscow, 2010).

${ }^{62}$ E. Hobsbawm, Nations and Nationalism since 1780. Programme, Myth, Reality (Cambridge, 1992), p. 87.

${ }^{63}$ B. Kolonitskii, 'The "Russian Idea” and the Ideology of the February Revolution', in T. Hara and K. Matsuzato (eds.), Empire and Society: New Approaches to Russian History (Sapporo, 1997), pp. 57-60.

${ }^{64}$ O. Figes and B. Kolonitskii, Interpreting the Russian Revolution. The Language and Symbols of 1917 (New Haven, 1999), p. 164.

${ }^{65}$ RGVIA, f. 2014, op. 1, d. 3, 1. 9-10ob (protocol of bureau meeting, 17 May 1917), 87ob, 89 (both from protocol, 19 August 1917).

${ }^{66}$ See Rendle, Defenders, pp. 166-8; and A. Wildman, 'Officers of the General Staff and the Kornilov Movement', in E. Frankel, J. Frankel, and B. Knei-Paz, eds., Revolution in Russia: Reassessments of 1917 (Cambridge, 1992), pp. 76-101.

${ }^{67}$ Report from the bureau to the Commander-in-Chief, 26 July 1917, RGVIA, f. 2003, op. 1, d. 1782, 11. 79-80. 
${ }^{68}$ Vestnik glavnago komiteta Soiuza Ofitserov Armii i Flota, No. 5, 24 August 1917, in GARF, f. 1780, op. 1, d. 71, 1. 38 .

${ }^{69}$ Letter from Grigor'ev, placed charge of procuring machinery, to the bureau, undated, RGVIA, f. 2014, op. 1, d. 3, 1. 124.

${ }^{70}$ Letter from the $2^{\text {nd }}$ Quartermaster General to the bureau, 10 July 1917, RGVIA, f. 2014, op. 1, d. $16,1.85$.

${ }^{71}$ RGVIA, f. 2014, op. 1, d. 3, 11. 76-76ob (letter from the bureau to Kornilov, 1 August 1917), 87-87ob (protocol of bureau meeting, 19 August 1917); d. 16, 11. 156 (letter from the bureau to the Chief of Staff, 10 August 1917), 192-92ob (letter from the Chief of Staff to the bureau, 5 August 1917), 295 (note from the bureau, 27 August 1917), 340 (letter from the bureau to the Chief of Staff, 12 September 1917).

${ }^{72}$ Letter from the bureau to the $2^{\text {nd }}$ Quartermaster General, 7 August 1917, RGVIA, f. 2003, op. 1, d. 1782, 11. 119-119ob.

${ }^{73}$ Telegram, 15 August 1917, RGVIA, f. 2014, op. 1, d. 16, 1. 252.

${ }^{74}$ RGVIA, f. 366, op. 2, d. 124, 11. 77-91 (numerous protests from soldiers' committees, midAugust 1917; f. 2014, op. 1, d. 16, 11. 256 (telegram from army committee of the $1^{\text {st }}$ Army, 16 August 1917), 259 (telegram from the executive committee of the south-west front, 16 August 1917), 263 (telegram from the army committee at Minsk, undated), 265 (telegram from the army committee of the $3^{\text {rd }}$ Army, undated).

${ }^{75}$ RGVIA, f. 2014, op. 1, d. 16, 11.257 (telegram from the Ministry of War to the bureau, 14 August 1917), 262 (telegram from the $2^{\text {nd }}$ Quartermaster General to the bureau, 16 August 1917).

${ }^{76}$ Report on the May congress from the chief committee of the Union of Officers for widespread distribution, 24 May 1917, GARF, f. 1780, op. 1, d. 71, 11. 49-49ob. 
${ }^{77}$ RGVIA, f. 2003, op. 1, d. 1782, 11.2 (report on a meeting of the chief committee of the Union of Officers, 13 June 1917), 19-21ob (chief committee of the Union of Officers to the Commander-in-Chief, 19 June 1917), 23-23ob (report on a meeting of the chief committee of the Union of Officers, undated), 89 (letter from Brusilov to the president of the Union of Officers, 20 June 1917).

${ }^{78}$ Novosil'tsev's memoirs, GARF, f. 6422, op. 1, d. 1, 1l. 153ob-156ob, 159, 172-175ob, 177ob.

${ }^{79}$ Telegram, 19 July 1917, RGVIA, f. 2003, op. 1, d. 1782, 11. 62-62ob.

${ }^{80}$ RGVIA, f. 2003, op. 1, d. 1782, 11. 45-46 (telegram from the Union of Officers to the staffs of all fronts, 8 July 1917), 66 (telegram from the chief committee of the Union of Officers to the staff of an unspecified front, 21 July 1917), 124-25 (telegram of B. V. Savinkov, deputy Minister of War, to the chief committee of the Union of Officers, 22 August 1917).

${ }^{81}$ See, for e.g., the correspondence between the Quartermaster General and the Chief of Staff of the $6^{\text {th }}$ Army, 24-27 July 1917, RGVIA, f. 2003, op. 1, d. 1782, 11. 68, 78.

${ }^{82}$ Letter from the $2^{\text {nd }}$ Quartermaster General to the bureau, 29 July 1917, RGVIA, f. 2014, op. 1, d. 16, 11. 166-166ob.

${ }^{83}$ Minutes of bureau meeting, 19 August 1917, RGVIA, f. 2014, op. 1, d. 3, 11. 85-90.

${ }^{84}$ Rendle, Defenders, pp. 158-80.

${ }^{85}$ List of participants in the Moscow Assembly, undated, GARF, f. 3529, op. 1, d. 7, 1. 2; minutes of bureau meeting, 19 August 1917, RGVIA, f. 2014, op. 1, d. 3, 1. 90.

${ }^{86}$ Protopresviter of military and naval clergy to the bureau, 19 July 1917, RGVIA, f. 2014, op. 1, d. 16, 1. 171.

${ }^{87}$ President of the Union of Officers to the bureau, 3 August 1917, RGVIA, f. 2014, op. 1, d. 16, 1. 197; GARF, f. 1780, op. 1, d. 73, 11. 41-41ob (appeal from the Union of Officers describing its 
history, achievements and objectives, 7 August 1917); d. 78, 1. 52 (report by the Military League on a meeting of military organizations, 31 July 1917).

${ }^{88}$ Letter from the chief committee of the Union of Officers to the Commander-in-Chief, 11 June 1917, RGVIA, f. 2003, op. 1, d. 1782, 11. 31-32ob.

${ }^{89}$ Minutes of bureau meeting, 19 August 1917, RGVIA, f. 2014, op. 1, d. 3, 1. 89ob.

${ }^{90}$ Wade, Russian Revolution, pp. 204-07; Wildman, End, II, pp. 184-223.

${ }^{91}$ Rendle, Defenders, pp. 180-6.

${ }^{92}$ Delo Kornilova, II, pp. 123-4.

${ }^{93}$ Resolution of the bureau, 28 August 1917, RGVIA, f. 2014, op. 1, d. 3, 1. 105.

${ }^{94}$ Delo Kornilova, II, p. 122.

${ }^{95}$ Delo Kornilova, II, pp. 45-8, 316-19.

${ }^{96}$ RGVIA, f. 2014, op. 1, d. 3, 11. 107-109ob (minutes of bureau meetings, 2-3 September 1917); d. 16, 11. 296-296ob (telegram from the bureau to the chief of staffs of all armies and both fleets, 3 September 1917).

${ }^{97}$ Various correspondence from Bragin to the bureau, August 1917, RGVIA, f. 2003, op. 1, d. 1796, 11. 1-10; letter from the bureau to the Chief of Staff, 12 September 1917, f. 2014, op. 1, d. 16, 11. 339-340ob.

${ }^{98}$ RGVIA, f. 2014, op. 1, d. 16, 11. 361-361ob (letter of introduction from the bureau for Ia. A. Kremnev, 22 September 1917), 388 (letter from the bureau to the Chief of Staff, 30 September 1917).

${ }^{99}$ Minutes of bureau meeting, 27 September 1917, RGVIA, f. 2014, op. 1, d. 3, 11. 117-118.

${ }^{100}$ Minutes, RGVIA, f. 2014, op. 1, d. 3, 1. 122. 
${ }^{101}$ Minutes of bureau meetings, RGVIA, f. 2014, op. 1, d. 3, 11.134 (12 November 1917), 136ob137 (15 November), 141-41ob (23 November), 142-43ob (25 November).

102 Anonymous telegram, undated, RGVIA, f. 2014, op. 1, d. 16, 1. 335.

${ }^{103}$ Wade, Russian Revolution, p. 216.

${ }^{104}$ S. Rudneva, Predparlament: Oktiabr' 1917g. (Moscow, 2006), p. 89.

${ }^{105}$ Letter from the bureau to the $2^{\text {nd }}$ Quartermaster General, 23 August 1917, RGVIA, f. 2003, op. 1, d. 1782, 11. 151-52.

${ }^{106}$ Minutes of bureau meeting, 27 October 1917, RGVIA, f. 2014, op. 1, d. 3, 11. 126-126ob.

${ }^{107}$ RGVIA, f. 2014, op. 1, d. 3, 11. 115-116 (instructions for those appointed to the chancellery of the bureau, 20 September 1917), 127-127ob (minutes of bureau meeting, 30 October 1917). ${ }^{108}$ Minutes of bureau meeting, 12 November 1917, RGVIA, f. 2014, op. 1, d. 3, 1. 134. 109 Abiniakin, Ofitserskii, p. 187.

${ }^{110}$ RGVIA, f. 2014, op. 1, d. 3, 11. 132-32ob (minutes of bureau meeting, 6 November 1917), 133 (appeal to all death, shock and revolutionary battalions, 1 November 1917), 134 (minutes of bureau meeting, 12 November 1917).

${ }^{111}$ Abiniakin, Ofitserskii, p. 44; Solntseva, 'Udarnye', pp. 51, 56-7.

${ }^{112}$ Minutes, RGVIA, f. 2014, op. 1, d. 3, 1. 130.

${ }^{113}$ See A. Shestakov, ed., Sovety krest'ianskikh deputatov i drugie krest'ianskie organizatsii: Tom pervyi, chast’ II (Moscow, 1929), pp. 181-209.

${ }^{114}$ See D. Orlovsky, 'Corporatism or Democracy: The Russian Provisional Government of 1917', in A. Weiner, ed., Landscaping the Human Garden (Stanford, 2003), pp. 67-90. 